\title{
THËAMERICAN MUSEUM
}

$\mathrm{QH} 70$

of

.452

N41123

1920

\section{IRAL HISTORY}

\section{Open Free Daily}

Weekdays from 9 a.m. to 5 p.m.

Sundays from 1 p.m. to $5 \mathrm{p.m}$. 


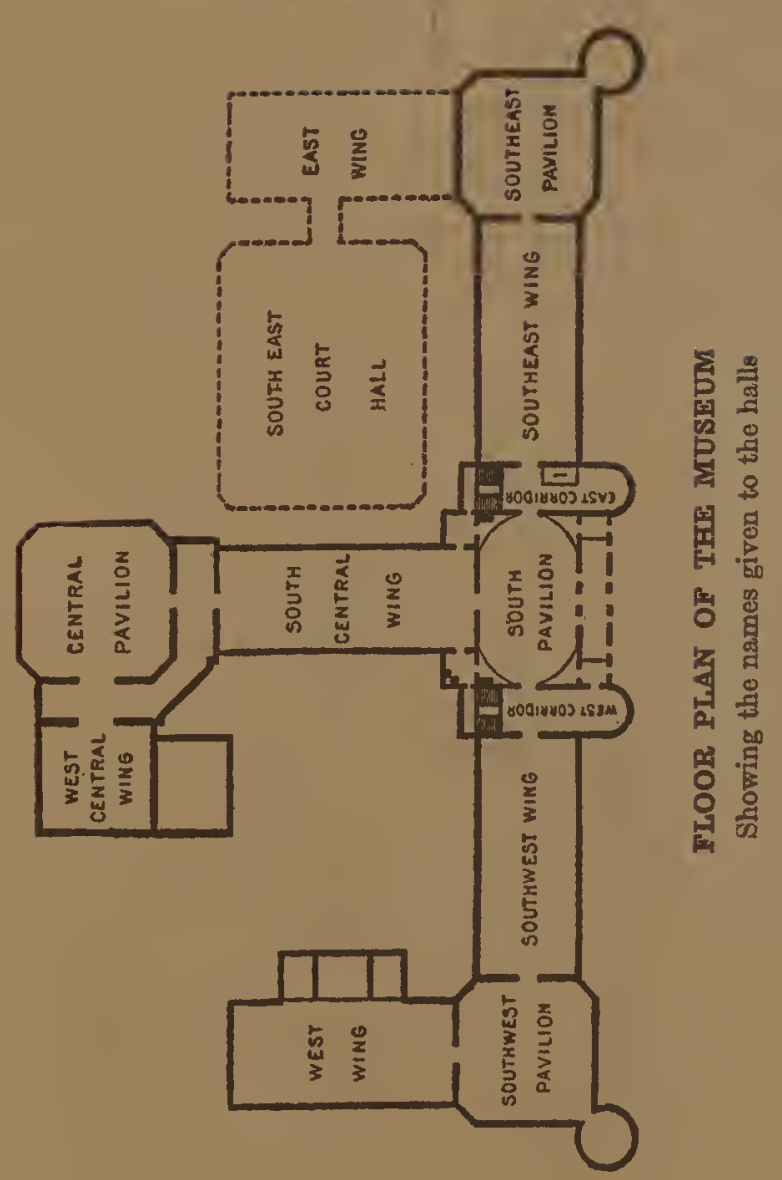




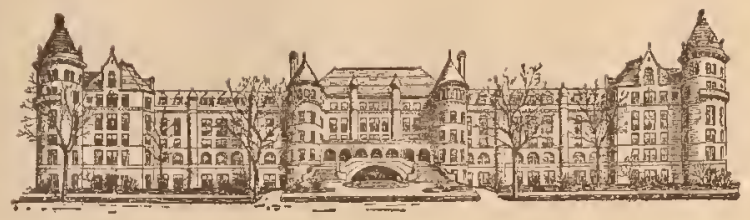

The Museum is 710 feet long, has ten acres of floor space, eight of which are devoted to exhibits, and has so far cost $\$ 5,319,821.48$

$$
20.81881 \cdot \text { moe } 5
$$

\section{AN HOUR}

IN

\section{THE AMERICAN IMUSEUM OF NATURAL HISTORY}

An hour is not enough in which to see the Museum, but some people, unfortunately, ean spare no more, and this leaflet which notes some of the prineipal objects of interest Las been prepared for their benefit.

It would take about half an hour merely to visit all the halls in the order laid down, but the visitor will doubtless proceed on the "skip-stop" principle, devoting the stops to those exhibits he -or she-finds most interosting.

The visitor enters Memorial Hall which eontains the largest known meteorite, "Ahnighito," 26 tons, and the most singular, the "Willamette." Another notable piece is the large boulder of Jadeite. Note the statue of Morris K. Jesup, benefactor of the Museum and for years its President, and on the walls busts of noted Ameriean men of science. Proceed to the east corridor where are maps of the north and south polar regions, showing the routes of famous explorers, and sledges that reached the north and south poles.

Then take elevator to the Fourth Floor and proeeer to the Southeast Pavilion. 


\section{FOURTH FLOOR}

Note, opposite the elevator, the great fish, Portheus; Pteranodon, the greatest flying creature, and the great marine reptile. Turn to the right and proceed to

SOUTHEAST PAVILION-Hall of Dinosaurs. Fossil Reptiles and Fishes; Brontosaurus, Tyrannosaurus, and other great Dinosaurs, Naosaurus, jaws of Giant Fossil Shark; Mummied Dinosaur.

SOUTHEAST WING-Fossil Mammals; Evolution of the Horse. This collection contains specimens of the earliest known ancestors of the Horse, and is the largest and finest known.

SOUTH PAVILION-Mastodons and Mammoths; Skeletons of Modern Horses, Warren Mastodon, the fincst specimen ever discovered. Series of specimens illustrating the "Age of Man." The fossils exhibited arc celebrated for their completeness, artistic pose and lifelike attitudes. Around the walls are paintings by Knight giving a very vivid idea of the appearance and haunts of many extinct animals.

SOUTH CENTRAL WING-Fossilized Tree Stump, Copper Queen and Weyer's Caves, Copper Queen Mine Model; General Gcological Collcction; Fossil Invertebrates.

Cross to

WEST WING-General Philippine Collection: Tree House, Head-axes, Bagobo Beadwork; Woods.

SOUTHWEST PAVILION-Natives of the Pacific Islands: Tahitian Fire-walker, Maori Warrior, Maori Tattooed Heads. Feather Capes, Tapa Cloth.

SOUTHWEST WING-General Collection of Minerals, one of the finest in the world.

WEST CORRIDOR-The Morgan Gem Collection, comprising Gems, Precious Stoncs, and objects of Jade.

Descend to Third Floor and proceed to Southeast Pavilion-Hall of Insect Life. 


\section{THIRD FLOOR}

SOUTHEAST PAVILION-Insects, their classification, habits and relations to man, illustrated by groups and many single specimens; note the group of Migratory Butterflies which contains 1200 specimens.

SOUTHEAST WING-Reproductions of Whales, Dolphins and Porpoises, including one of a Blue Whale 76 feet long; Development of Mammals.

SOUTH PAVILION-Man and Apcs. Monkeys of the World, shown by many groups and single speeimens. The groups of Orang Utans and African Pigmies show the contrast between the higher apes and one of the lower raecs of mankind.

SOUTH CENTRAL WING-IIabitat Groups of North American birds, preëminent for their trutlfful portrayal of the life of birds in their native haunts.

Procecd to

WEST WING-Exhibit of Shells-15,000 species are shown: the Giant Clam near the entrance wcighs 579 pounds, and is perhaps the largest known.

SOUTHWEST PAVILION-Arts and Industries of China: Bronzes, Porcelain, Embroidery and Carvings in Wood, Stone and Ivory. Clothing, Utensils and War Implcments from Siberia.

SOUTHWEST WING-Gold, Silver, Pottery and Stone Objects from South Amcrica; Prehistoric Textiles, Mummies from Peru and Chilc.

WEST CORRIDOR-Exhibits of Department of Public Health. Beautiful models of Fly and Mosquito. How discases are spread and how thcy may he prevented.

Descend to Sccond Floor and proceed to Southeast Wing-Mammals of North America. 


\section{SECOND FLOOR}

SOUTHEAST PAVILION-Being used for the mounting of a group of elephants and other African Mammals. Not open to visitors.

SOUTHEAST WING-Mammals of North America. Moose, Bison, Fur Seal, Polar Bear, Mountain Goat, Musk-ox, Caribou, Beaver, Elk and other Groups.

SOUTH PAVILION-Reptile Life of Florida. Toad, Frog, Salamander, Lizard, and Snake Groups. Penguins and Sea Eleplants.

SOUTH CENTRAL WING-Birds of the World, their classification and distribution. Dodo, Great Auk, Labrador Duck, Wild Pigeon, Birds of Paradise. Recent Fishes, Giant Manta.

CORRIDOR OF CENTRAL PAVILION-Paddle-fish and other Groups; Sharks and Occan Sunfish, and Luminous Fishes of the Deep Sea.

Cross to the

WEST WING Collections from the Congo. African Mammals, Okapi and White Rhinoceros.

SOUTHWEST PAVILION-Early Man in America and Europe. Stonc Implements, Rude Carvings and Paintings made by Prehistoric Man.

SOUTHWEST WING-Ancient Monuments of Mexico and Central America; Keith Gold, Stone and Pottery Collection; Ancient Maya Documents.

WEST CORRIDOR-Birds found in the vicinity of New York City.

Descend to First Floor and proceed to Southeast Pavilion-Darwin Hall. 


\section{FIRST FLOOR}

SOUTHEAST PAVILION-Darwin Hall: Malaria Mosquito, Tide Pool, Wharf Pile, and other Marine and Shore Groups; exhibits illustrating Variation under Domestication, Variation in Nature and Struggle for Existence. Beautiful models in glass of Invertebrates.

SOUTHEAST WING -Jesup Collection of North American Woods. Examples of all kinds accompanied by reproductions of their foliage. The section of Sequoia at the left was 1341 years old, but was still a young and vigorous tree.

SOUTH CENTRAL WING-Seismograph, Indians of the Pacific Coast, Haida Canoe, Totem Poles, Chilkat Blankets, Murals. In the colridor beyond are the Eskimo collections, Meteorites and Building Stones.

Cross to the

WEST WING-Indians of the Southwest. Hopi and Apache Groups, Navajo Blankets, Pottery, Baskcts.

SOUTHWEST PAVILION-Indians of the Plains. Indian Tipi, Sun Dance Group, Buffalo Robes, Beadwork.

SOUTHWEST WING-Indians of the Eastern Woodlands. Wampum, Masks, Clothing, Canoes.

This completes the tour of the museum and it is hoped that what has been seen will lead the visitor to wish to come again.

A General Guide and Series of Souvenir Stamps in color will serve to recall some of the objects seen. 

盯 馬 m A ह छ

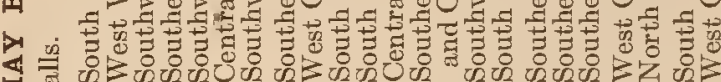
崖

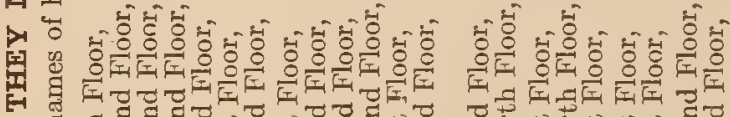

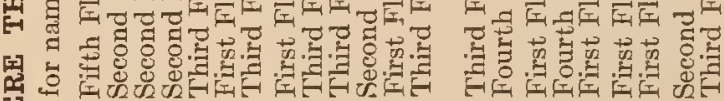

舫

是苍

2)

空

舟

E-

되 0 년

ค.

争 :

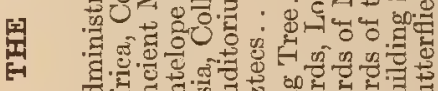

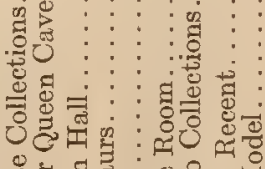
क⿺辶 :

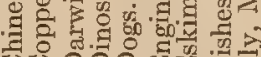

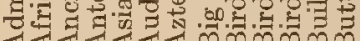

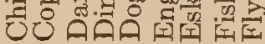




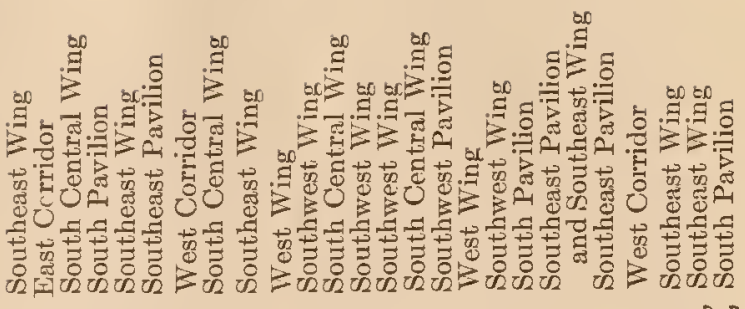

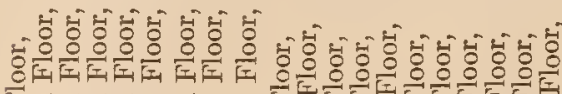

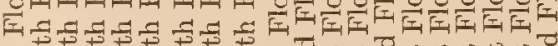
w

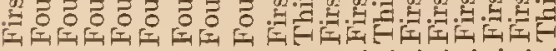

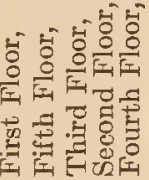

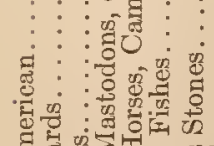
先.

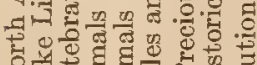

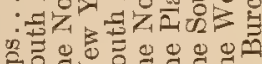

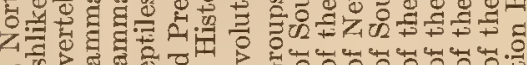

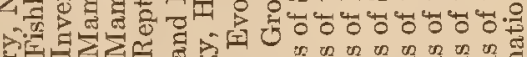

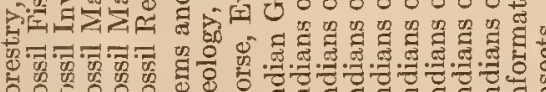

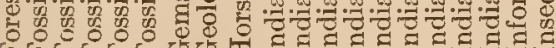

年

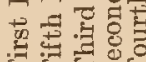




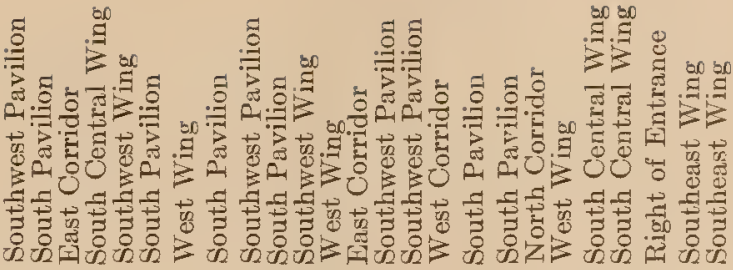

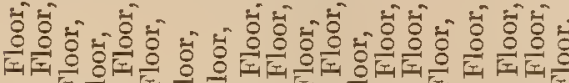

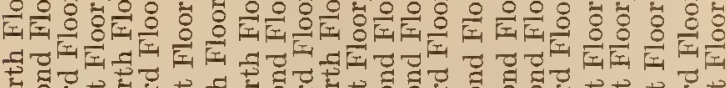

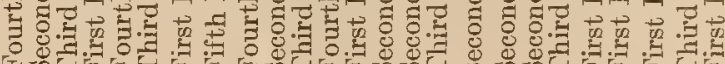

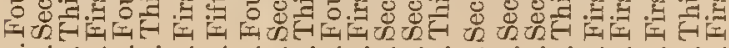

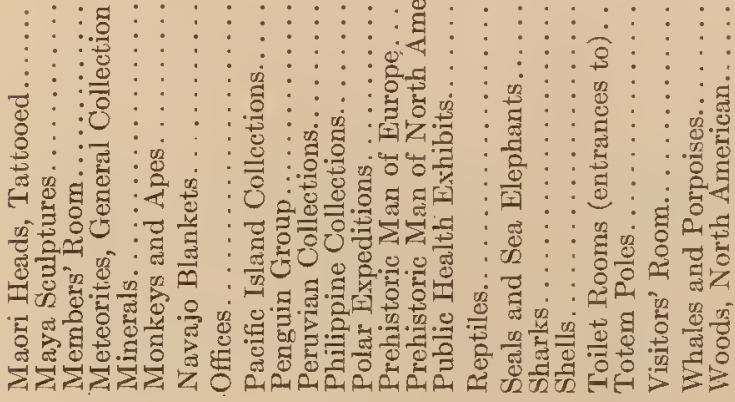




\section{HOW TO REACR TER MOBEUM}

The Museum is located at 77 th Street and Central Park West, and can be reached by the 8th or 9 th Avenue surface cars, the 6th or gth Avenue elevated to 8ist Street station, or by the subway to $72 \mathrm{~d}$ or 79 th Street station. The Museum is open free every day in the year; on week days, including holidays, from $9 \mathrm{a} . \mathrm{m}$. to $5 \mathrm{p} . \mathrm{m} .$, on Sundays from $\mathrm{x}$ to $5 \mathrm{p} . \mathrm{m}$.

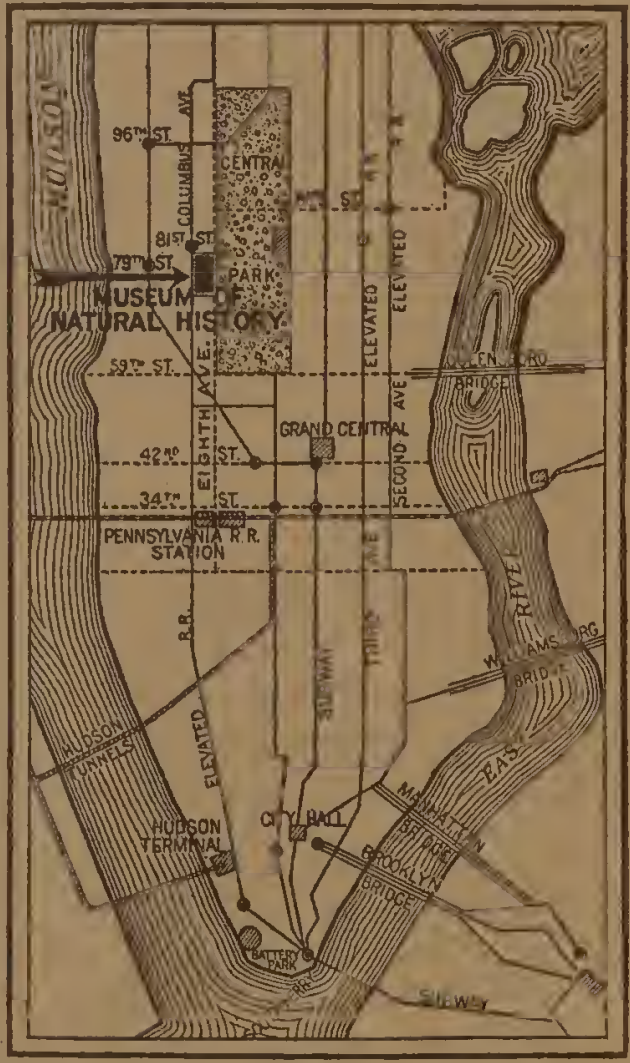

From the Grand Central Station take Broadway surface car to 77 th Street, or subway shurtle to Times Square and local to 79 th Street.

From the Pennsylvania Station take the 8th Avenue surface cars, or the subway local to 79 th Street. 
